\title{
The Relative Ability of Earnings and Cash Flow Data in Forecasting Future Cash flows: Some Australian Evidence
}

\author{
Shadi Farshadfar, Chew Ng and Mark Brimble* \\ Griffith Business School \\ *Department of Accounting, Finance and Economics \\ Griffith University, Brisbane, Australia. \\ Ph (07) 33821355 \\ m.brimble@griffith.edu.au
}

Acknowledgement: The authors thank $\mathrm{Dr}$ Reza Monem, two anonymous referees, participants in the research seminar at Griffith University, and the Accounting and Finance Association of Australia and New Zealand Conference (2006, Wellington) for their helpful comments and suggestions on the earlier drafts of this paper. 


\section{Structured Abstract}

Purpose: This paper examines the relative predictive ability of earnings, cash flow from operations as reported in the cash flow statement, and two traditional measures of cash flows (i.e. earnings plus depreciation and amortisation expense, and working capital from operations) in forecasting future cash flows for Australian companies. Further, an empirical investigation of the extent to which firm size, as a contextual factor, influences the predictability of earnings and cash flow from operations is presented.

Methodology: Our sample includes 323 companies listed on the Australian Stock Exchange between 1992 and 2004 (3,512 firm-years). We employ the ordinary least squares and fixedeffects approaches to estimate our regression models. To evaluate the forecasting performance of the regression models, both within-sample and out-of-sample forecasting tests are employed.

Findings: We provide evidence that reported cash flow from operations has more power in predicting future cash flows than earnings and traditional cash flow measures. Further, the predictability of both earnings and cash flow from operations significantly increases with firm size. However, the superiority of cash flow from operations to earnings in predicting future cash flows is robust across small, medium and large firms.

Key Words: Accrual-based earnings, Cash flow from operations, Funds-based cash flow measures, Firm size, Forecasting future cash flows, Australia

Paper Type: Research Paper 


\section{Introduction}

Providing new evidence on the relative informativeness and predictive ability of earnings and cash flow measures appears to be of particular significance and renewed importance given recent corporate collapses (e.g. Enron, World.Com, HIH Insurance, One.Tel among others) in the US and Australia. These events have drawn considerable attention from accounting financial statement users and regulators to the quality and usefulness of accounting measures, particularly those related to firms’ financial performance.

Accordingly, the main objective of our study is to provide some Australian evidence on the relative usefulness of accrual-based earnings and cash flow from operations as reported in the cash flow statement in forecasting future cash flows. The differential predictability of reported cash flow from operations and two traditional (funds-based) measures of cash flows (i.e. earnings plus depreciation and amortization expense, and working capital from operations) are also compared. In addition, we investigate the extent to which incorporating firm size, as a contextual factor, affects the relationship between earnings, reported cash flow from operations and future cash flows.

To achieve the objectives of our study, we analyse a sample of 3,512 firm-years comprising 352 Australian firms between 1992-2004. We employ four univariate ordinary least squares (OLS) regression models. The forecasting performance of the models is assessed using both within-sample and out-of-sample forecasting tests. In addition, the results of the OLS regression models are re-examined within a more 
sophisticated regression approach called fixed-effects, which allows intercepts to vary across firms.

We focus on future cash flows as the predictive criterion, as they are of significant relevance to the users of accounting information in their various decision-making contexts, such as investing and lending (e.g. Bowen et al., 1986; Neill et al., 1991). This criterion is also in accordance with the main objective of reporting financial statements as determined by accounting standard setters. For example, in Australia, under Statement of Accounting Concepts 2: Objective of General Purpose Financial Reporting one of the reasons for which user groups (e.g. investors and creditors) require financial reporting is that they are interested in assessing the ability of companies to generate future cash flows, as their economic decisions are influenced by this information (Australian Accounting Research Foundation and Accounting Standards Review Board, 1990, para. 21). In the US, the Financial Accounting Standards Board (FASB) in Statement of Financial Accounting Concepts 1: Objectives of Financial Reporting by Business Enterprises similarly states that one of the major aims of financial reporting is to provide information which enables users to assess amounts, timing and uncertainty of future cash flows (FASB, 1978, para. 37).

In line with the above views, accounting standard setters across the world have required firms to disclose the cash flow statement as an integral part of financial reporting. In Australia, the Australian Accounting Standards Board (AASB) issued AASB 1026: Statement of Cash Flows in December 1991, which made it mandatory to disclose the 